\title{
The significance of increased levels of end nitric oxide metabolites in blood serum of children with celiac disease
}

\author{
Uspenskaya ID ${ }^{1}$, Erzutova MV ${ }^{1}$, Korkotashvili LV, ${ }^{2}$ Kolesov $\mathrm{SA}^{2}$, Shirokova NY3 \\ Division of Small Intestine Pathology, Nizhny Novgorod Federal Research Institute of Pediatric Gastroenterology, \\ Nizhny Novgorod, Russia. iusp@mail.ru
}

\begin{abstract}
Objectives: The aim of the study was to determine serum nitric oxide (NO) metabolites and correlate them to gluten-free diet (GFD) compliance, the parameters of morphological and functional condition of the small intestine in patients with celiac disease (CD) in a long-term follow-up.

Patients and methods: The study included 35 children (age median 8.0 years) with previously diagnosed CD, among them 15 - on a strict GFD and 20 - on a semistrict GFD. 32 patients (age median 7.5 years) with functional abdominal pain were recruited as controls. Nitrites $\left(\mathrm{NO}_{2}\right)$, nitrates $\left(\mathrm{NO}_{3}\right)$, total content of nitrites and nitrates (NOx) in serum were determined using the Griess reaction. CD patients underwent small intestine morphometry and absorption D-xylose test.

Results: Compared to the controls, the CD patients on a strict GFD had no significant differences in $\mathrm{NO}_{2}, \mathrm{NO}_{3}$, NOx content, while in patients violating GFD these parameters were significantly higher. In comparison with the patients on a strict GFD, the patients on a semistrict GFD had higher median values of $\mathrm{NO}_{3}(p=0.002)$ and NOx $(p=0.0000)$. Serum NOx correlated negatively with the height of villi $(p=0.0001)$, D-xylose excretion $(p=0.0063)$, and correlated positively with the depth of crypts $(p=0.0082)$ and cellular density of villi stroma $(p=0.0067)$. Conclusion: CD patients not keeping to a strict GFD have an increased level of nitric oxide metabolites in serum. NOx content is associated with morphometric parameters of the small intestine that proves the participation of $\mathrm{NO}$ in the pathogenesis of histological changes in CD (Tab. 3, Ref. 39). Text in PDF www.elis.sk. Key words: celiac disease, follow-up, nitric oxide, nitrite, nitrate.
\end{abstract}

Celiac disease (CD) is chronic, immunologically determined form of enteropathy affecting the small intestine in genetically predisposed children and adults (1). At present, epidemiological studies in different countries indicate significant prevalence rate of the pathology among the population from $0.3 \%$ to $2 \%(2-4)$. The highest risk of the disease is associated with the presence of genetic markers of HLA-DQ2 and HLA-DQ8 molecules. CD is provoked by intake of wheat, rye, barley products, which contain gluten and gluten-related gramineous proteins. In CD, gluten has toxic effect on small intestine promoting an immuno-inflammatory process in intestinal mucosa and secreting proinflammatory cytokines that can result in atrophy of intestinal villi, malabsorption, and various clinical presentations (5-7).

Inflammation is known to be associated with the production of nitric oxide (NO) and its transmutation products $(8,9)$. Duodenal mucosa of CD patients was found to have significant increase of

${ }^{1}$ Division of Small Intestine Pathology, Nizhny Novgorod Federal Research Institute of Pediatric Gastroenterology, Nizhny Novgorod, Russia, ${ }^{2}$ Laboratory and Diagnostic Department, Biochemical Laboratory, Nizhny Novgorod Federal Research Institute of Pediatric Gastroenterology, Nizhny Novgorod, Russia, and ${ }^{3}$ Laboratory and Diagnostic Department, Pathologic Laboratory, Nizhny Novgorod Federal Research Institute of Pediatric Gastroenterology, Nizhny Novgorod, Russia

Address for correspondence: I.D. Uspenskaya, MD, Division of Small Intestine Pathology, Nizhny Novgorod Federal Research Institute of Pediatric Gastroenterology, Semashko Street, 22, Nizhny Novgorod, 603950, Russia. Phone/fax: +78314365659 activity of inducible nitric oxide synthase (iNOS) that results in increased production of $\mathrm{NO}$ and total level of stable end-products of its oxidation $(\mathrm{NOx})$, i.e., nitrites $\left(\mathrm{NO}_{2}\right)$ and nitrates $\left(\mathrm{NO}_{3}\right)(10,11)$.

The increased level of nitric oxide metabolites was found in urine of children with $\mathrm{CD}$ (12), and proved by other authors as well (13). High content of nitric oxide metabolites was also found in plasma and serum of untreated CD patients $(14,15)$. A followup for several months after diagnosis verification and treatment administration in CD patients showed a decreased level of plasma nitric oxide products (16).

A life-long strict gluten-free diet (GFD) is recognized to be the only treatment modality of $\mathrm{CD}$ and prevention of its complications (17). However, due to various reasons, not all patients adhere to a strict GFD after diagnosis of CD $(18,19)$.

Potential clinical value of the measurement of nitric oxide products in blood serum of CD patients in long-term follow-up after diagnosis is understudied.

In our view, the solution of the problem by means of minimally invasive technique will enable to control GFD observation in CD patients and the dynamics of the process in the small intestine; and contribute to the extension of an idea of NO involvement in mechanisms participating in the change of the structure of intestinal mucosa in CD.

The objective of the present study was to assess the level of nitric oxide metabolites in serum of children with $\mathrm{CD}$ in a longterm follow-up, and to investigate a possible relationship between the level of nitric oxide metabolites and gluten-free diet compli- 
ance, the indices of morphological and functional condition of intestinal mucosa.

\section{Patients and methods}

We examined 35 children including 10 boys and 25 girls (median age 8.0 years) with classical celiac disease $1.5-14.5$ years after CD diagnosis based on revised criteria of the European Society for Pediatric Gastroenterology, Hepatology and Nutrition (20).

Special interviewing showed that $15(42.9 \%)$ out of 35 patients kept to a strict GFD, and 20 (57.1\%) children partially violated the diet (semistrict GFD).

Inclusion criteria for patients were the following: age from 3 to 17 years, follow-up period from 1.5 years and longer after diagnosis verification, the confirmation of the diagnosis of $\mathrm{CD}$ according to previous serological and histological examination prior to GFD prescription, and patient Informed Consent. Exclusion criteria were: age under 3 and over 17 years, a follow-up period less than 1.5 years, untreated $\mathrm{CD}$, the presence of concomitant acute respiratory disease, the lack of an informed consent of patients and their parents.

Control group included 32 children with functional abdominal pain: 12 boys and 20 girls (median age 7.5 years). Patients of both groups (CD group and control group) were comparable by age ( $\mathrm{p}$ $=0.6915)$ and $\operatorname{sex}(\mathrm{p}=0.6031)$.

Blood samples for biochemical study were taken in the morning, after at least 8-hour fasting period, by cubital vein puncture. Serum was received by standard methods. Serum samples were drawn in all examined patients to determine nitric oxide metabolites and other biochemical parameters. Total nitrites and nitrates and nitric oxide content were evaluated by the Greiss reaction, and nitrates were reduced into nitrites using vanadium chloride. We took nitrite content from total nitric oxide metabolites to determine nitrate concentration. The sum of nitrites and nitrates was measured as an indirect variable of NO production. The results of the analysis were recorded using microplate photometer Multiskan Ascent (Labsystems Oy, Finland) with wavelength of $540 \mathrm{~nm}(21,22)$.

Hemoglobin concentration was measured by hematological analyzer ABX Pentra 60 (HORIBA ABX, France). Serum albumin level was measured using automatic biochemical analyzer CA-180 (FURUNO, Japan).

All patients with CD underwent gastrointestinal endoscopy with target biopsy of mucosa from distal duodenum. The samples were fixed in $10 \%$ neutral formalin, and then embedded in paraffin, cut $5 \mu \mathrm{m}$ thick, stained by hematoxylin and eosin for the following light microscopy and morphometry. The samples were studied by 2 pathologists with long-term experience in morphometric analysis, who did not know the research topic. Well-oriented biopsy samples were studied by the length of villi, the depth of crypts, the number of intraepithelial lymphocytes (per 100 enterocytes), as well as total cellular density in a square millimeter of lamina propria villi and the space between the crypts using a microscope Nikon Eclipse E400, and quantitative morphometric indices of intestinal mucosa condition were obtained.

To assess intestinal absorption in CD patients we used urinary D-xylose test performed according to standard technique, calculating a fraction of xylose dose excreted in 5 hours in urine. The findings of urinary D-xylose test were expressed in $\%$.

The research was in compliance with local biomedical ethics committee requirements of Nizhny Novgorod Federal Research Institute of Pediatric Gastroenterology developed according to

Tab. 1. Demographic and laboratory parameters of subjects.

\begin{tabular}{|c|c|c|c|c|c|}
\hline \multirow[b]{2}{*}{ Parameters } & \multirow{2}{*}{$\begin{array}{l}\text { Control group } \\
n=32\end{array}$} & \multirow{2}{*}{$\begin{array}{l}\text { Total CD patients } \\
\qquad \mathrm{n}=35\end{array}$} & \multicolumn{2}{|c|}{ CD patients } & \multirow[b]{2}{*}{$\mathrm{p}$} \\
\hline & & & $\begin{array}{c}\begin{array}{c}\text { Strict GFD } \\
\mathrm{n}=15\end{array} \\
\end{array}$ & $\begin{array}{c}\text { Semistrict GFD } \\
\mathrm{n}=20\end{array}$ & \\
\hline Age, years & $\begin{array}{c}7.5 \\
(5.75-12.0)\end{array}$ & $\begin{array}{c}8.0 \\
(6.0-11.0)\end{array}$ & $\begin{array}{c}8.0 \\
(6.0-10.5)\end{array}$ & $\begin{array}{c}9.5 \\
(6.0-13.0)\end{array}$ & 0.6915 \\
\hline Sex (male/female) & $12 / 20$ & $10 / 25$ & $3 / 12$ & $7 / 13$ & 0.6031 \\
\hline Blood hemoglobin, g/l & $\begin{array}{c}134.0 \\
(122.0-140.5)\end{array}$ & $\begin{array}{c}131.0 \\
(122.5-139.3)\end{array}$ & $\begin{array}{c}130.0 \\
(123.0-138.0)\end{array}$ & $\begin{array}{c}134 \\
(125.0-138.5)\end{array}$ & 0.5949 \\
\hline Serum albumin, $g / 1$ & $\begin{array}{c}44.25 \\
(40.75-45.90) \\
\end{array}$ & $\begin{array}{c}43.85 \\
(41.50-46.98)\end{array}$ & $\begin{array}{c}44.50 \\
(40.90-47.48)\end{array}$ & $\begin{array}{c}43.55 \\
(42.00-46.53)\end{array}$ & 0.5096 \\
\hline Villi height, $\mu \mathrm{m}$ & - & $\begin{array}{c}385.0 \\
(308.0-427.0) \\
\end{array}$ & $\begin{array}{c}441.0 \\
(406.0-456.5) \\
\end{array}$ & $\begin{array}{c}329.0 \\
(285.3-368.0) \\
\end{array}$ & 0.0000 \\
\hline Crypt depth, $\mu \mathrm{m}$ & - & $\begin{array}{c}170.0 \\
(156.0-180.5) \\
\end{array}$ & $\begin{array}{c}163.0 \\
(156.0-166.5) \\
\end{array}$ & $\begin{array}{c}173.5 \\
(163.0-228.0) \\
\end{array}$ & 0.0180 \\
\hline IEL/100 villi enterocytes & - & $\begin{array}{c}19.0 \\
(16.5-24.0)\end{array}$ & $\begin{array}{c}19.0 \\
(17.0-21.0)\end{array}$ & $\begin{array}{c}21.0 \\
(16.0-26.5)\end{array}$ & 0.4819 \\
\hline Cell density intravillus & - & $\begin{array}{c}9709.0 \\
(9238.0-10593.5)\end{array}$ & $\begin{array}{c}9238.0 \\
(9097.0-9568.0)\end{array}$ & $\begin{array}{c}10275.0 \\
(9521.0-10982.3) \\
\end{array}$ & 0.0092 \\
\hline $\begin{array}{l}\text { Cell density in the space be- } \\
\text { tween crypts }\end{array}$ & - & $\begin{array}{c}10558.0 \\
(9362.0-11123.0)\end{array}$ & $\begin{array}{c}9804.0 \\
(9144.0-10511.0)\end{array}$ & $\begin{array}{c}10841.0 \\
(10150.3-11383.0)\end{array}$ & 0.0170 \\
\hline $\mathrm{D}-\mathrm{xylose} \%$ of dose $/ 5 \mathrm{~h}$ & - & $\begin{array}{c}28.85 \\
(25.38-34.55) \\
\end{array}$ & $\begin{array}{c}32.29 \\
(28.68-40.25)\end{array}$ & $\begin{array}{c}26.80 \\
(21.70-29.63) \\
\end{array}$ & 0.0185 \\
\hline
\end{tabular}

CD - celiac disease, IEL - intraepithelial lymphocytes.

Cell density is expressed as the number of total cells per $1 \mathrm{~mm} 2$ of lamina propria. Data are presented as median (interquartile range) unless otherwise indicated, and calculated using the Mann-Whitney U test for continuous variables, and Fisher's exact test for categorical variables. 
Tab. 2. The level of end products of nitric oxide metabolites in serum of patients with celiac disease (CD) and control group.

\begin{tabular}{|c|c|c|c|c|c|}
\hline \multirow[b]{2}{*}{ Parameters } & \multirow[b]{2}{*}{$\begin{array}{l}\text { Control group } \\
\mathrm{n}=32 \\
\text { (1) }\end{array}$} & \multirow[b]{2}{*}{$\begin{array}{l}\text { Total CD patients } \\
\mathrm{n}=35 \\
(2)\end{array}$} & \multicolumn{2}{|c|}{ CD patients } & \multirow[b]{2}{*}{$\begin{array}{l}\text { P value } \\
\text { (U-test) }\end{array}$} \\
\hline & & & $\begin{array}{c}\text { Strict GFD } \\
n=15 \\
(3)\end{array}$ & $\begin{array}{c}\text { Semistrict GFD } \\
\mathrm{n}=20 \\
(4)\end{array}$ & \\
\hline $\begin{array}{l}\mathrm{NO} 2, \mu \mathrm{mol} / 1 \\
\mathrm{p} \text { value } 0.0280 \\
(\mathrm{~K}-\mathrm{W})\end{array}$ & $\begin{array}{c}12.35 \\
(8.40-15.48)\end{array}$ & $\begin{array}{c}14.60 \\
(9.53-22.95)\end{array}$ & $\begin{array}{c}11.70 \\
(9.33-18.10)\end{array}$ & $\begin{array}{c}18.40 \\
(10.55-28.80)\end{array}$ & $\begin{array}{l}\text { p1-2 }=0.0333 \\
\text { p1-3 }=0.4651 \\
\text { p1-4 }=0.0099 \\
\text { p3-4 }=0.0890\end{array}$ \\
\hline $\begin{array}{l}\mathrm{NO} 3, \mu \mathrm{mol} / 1 \\
\mathrm{p} \text { value } 0.0005 \\
(\mathrm{~K}-\mathrm{W})\end{array}$ & $\begin{array}{c}17.20 \\
(10.30-30.03)\end{array}$ & $\begin{array}{c}29.10 \\
(17.90-54.65)\end{array}$ & $\begin{array}{c}21.30 \\
(10.10-26.95)\end{array}$ & $\begin{array}{c}44.75 \\
(30.60-72.63)\end{array}$ & $\begin{array}{l}\text { p1-2 }=0.0192 \\
\text { p1-3 }=0.9091 \\
\text { p1-4 }=0.0003 \\
\text { p3-4 }=0.0020\end{array}$ \\
\hline $\begin{array}{l}\mathrm{NOx}, \mu \mathrm{mol} / 1 \\
\mathrm{p} \text { value } 0.0000 \\
(\mathrm{~K}-\mathrm{W})\end{array}$ & $\begin{array}{c}31.25 \\
(23.08-40.23)\end{array}$ & $\begin{array}{c}54.90 \\
(35.40-69.70)\end{array}$ & $\begin{array}{c}35.10 \\
(26.25-37.25)\end{array}$ & $\begin{array}{c}66.45 \\
(56.63-93.00)\end{array}$ & $\begin{array}{l}\text { p1-2 }=0.0002 \\
\text { p1-3 }=0.7064 \\
\text { p1-4 }=0.0000 \\
\text { p3-4 }=0.0000\end{array}$ \\
\hline
\end{tabular}

$\mathrm{NO}_{2}$ - nitrite, $\mathrm{NO}_{3}$ - nitrate, $\mathrm{NOx}$ - nitrite/nitrate. Data are presented as median (interquartile range) unless otherwise indicated. K-W Kruskal-Wallis $\mathrm{H}$-test, U Mann-Whitney $U$ test, $\mathrm{p}-$ level of significance, $\mathrm{p}_{1-2}$ - statistically significant differences between group 1 and $2, \mathrm{p}_{1-3}-$ statistically significant differences between group 1 and 3 , $\mathrm{p}_{1-4}$ - statistically significant differences between group 1 and $4, p_{3-4}$ - statistically significant differences between group 3 and 4 .

World Medical Association's Declaration of Helsinki, and a signed informed consent was obtained from each patient and his parents.

Statistical analysis was performed using software environment for statistical computing R, version 2.15 (23).

Shapiro-Wilk test was used to control the normality of distribution of the indices. We used Levene test for homogeneity of variances. Since Gauss distribution and homogeneity of variances were not confirmed, nonparametric techniques were applied. Continuous variables were represented as medians (Me) and interquartile intervals and analyzed using Kruskal-Wallis H-test and Mann-Whitney U test. Categorical variables were expressed as counts and analyzed using Fisher's exact test. The correlations between NOx and other laboratory parameters were studied by Spearman's coefficient. The differences were considered statistically significant at a significance level of $p<0.05$.

\section{Results}

Table 1 represents demographic and laboratory parameters of control children and $\mathrm{CD}$ patients (total $\mathrm{CD}, \mathrm{CD}$ on a strict GFD, $\mathrm{CD}$ on a semistrict GFD). The comparison of routine laboratory parameters between the general group of CD patients and the control group did not reveal any statistically significant differences in hemoglobin level $(\mathrm{p}=0.6915)$ and serum albumin level $(\mathrm{p}=$ 0.5096). There were no significant differences in hemoglobin and albumin levels between the control patients and those with $\mathrm{CD}$ on a strict GFD, and between the control patients and those with CD on a semistrict GFD.

The mucosal condition examined by morphometric findings differed in CD patients on a strict GFD and those on a semistrict GFD. Compared to the patients keeping to a strict GFD, in patients violating a strict GFD the height of villi was lower $(p=0.0000)$, and it was larger than crypt depth value $(p=0.0180)$, cellular density of lamina propria in villi $(p=0.0092)$ and the space between the crypts $(p=0.0170)$. Urinary D-xylose excretion was higher in patients on a strict GFD than in those on a semistrict GFD $(p=0.0185)$.
Table 2 demonstrates the investigation results of the end products of nitric oxide metabolites. The comparison of the two groups: total CD patients and control children showed the group of total $\mathrm{CD}$ patients to have higher values of $\mathrm{NO}_{2}(\mathrm{p}=0.0333), \mathrm{NO}_{3}(\mathrm{p}=$ $0.0192)$, and their total content: NOx in serum $(p=0.0002)$. The assessment of the parameters of products of nitric oxide metabolites using Kruskal-Wallis H-test revealed significant differences between the three groups: controls, CD patients on a strict GFD, and patients on a semistrict GFD by median values $\mathrm{NO}_{2}(\mathrm{p}=$ $0.0280), \mathrm{NO}_{3}(\mathrm{p}=0.0005)$ and $\mathrm{NOx}(\mathrm{p}=0.0000)$.

In comparison with the control group $\mathrm{CD}$ patients on a strict GFD had no significant differences in content of $\mathrm{NO}_{2}(\mathrm{p}=0.4651)$, $\mathrm{NO}_{3}(\mathrm{p}=0.9091)$, NOx $(\mathrm{p}=0.7064)$, while $\mathrm{CD}$ patients on a semistrict GFD compared to controls had statistically significantly higher level of serum $\mathrm{NO}_{2}(\mathrm{p}=0.0099), \mathrm{NO}_{3}(\mathrm{p}=0.0003)$, NOx $(p=0.0000)$. As compared to the children on a strict GFD, those on a semistrict GFD showed higher median values of $\mathrm{NO}_{3}(21.30$ $\mu \mathrm{mol} / 1$ versus $44.75 \mu \mathrm{mol} / \mathrm{l} ; \mathrm{p}=0.0020)$ and NOx $(35.10 \mu \mathrm{mol} / 1$ versus $66.45 \mu \mathrm{mol} / 1 ; \mathrm{p}=0.0000)$.

Table 3 shows the correlation analysis. Spearman rank correlation analysis performed in all $\mathrm{CD}$ patients revealed negative correlation between NOx concentration and the height of duodenal mucosal villi $(p=0.0001)$ and the value of absorption test with

Tab. 3. Correlation analysis between serum NOx level and other laboratory parameters in celiac disease $(n=35)$.

\begin{tabular}{lcc}
\hline & \multicolumn{2}{c}{ General correlations } \\
\cline { 2 - 3 } & Spearman's Rho & $\mathrm{p}$ \\
\hline Villi height & -0.59 & 0.0001 \\
\hline Crypt depth & 0.44 & 0.0082 \\
\hline IEL & 0.13 & 0.4415 \\
\hline Cell density intravillus lamina propria & 0.45 & 0.0067 \\
\hline $\begin{array}{l}\text { Cell density of lamina propria in the } \\
\text { space between crypts }\end{array}$ & 0.35 & 0.0390 \\
\hline D-xylose excretion & & \\
\hline
\end{tabular}

IEL - intraepithelial lymphocytes 
urinary D-xylose $(p=0.0063)$. NOx level correlated positively with the depth of crypts $(\mathrm{p}=0.0082)$, total cellular density of lamina propria villi $(\mathrm{p}=0.0067)$ and total cellular density of lamina propria of the space between the crypts $(p=0.0390)$. There was no correlation between NOx level and intraepithelial lymphocyte count $(\mathrm{p}=0.4415)$.

\section{Discussion}

Currently, there is a great demand for the development of tests useful in the monitoring of CD patients in a long-term follow-up period that is of primary importance for the disease outcome and has an effect on health care system costs (24).

The aim of the present study was to determine the levels of nitric oxide metabolites in serum and reveal possible relationship between them and gluten-free diet compliance, indices of morphological and functional condition of intestinal mucosa in children with $\mathrm{CD}$ in a long-term follow-up.

The present study found that compared to control group, the levels of NO oxidates (i.e. nitrites, nitrates and their total content) in serum of patients on a strict GFD had no statistical differences, while in CD patients keeping to a semistrict GFD these indices were significantly higher. $\mathrm{NO}_{3}$ and $\mathrm{NOx}$ concentrations in patients on a semistrict GFD were statistically significantly higher than in patients keeping on a strict GFD.

The data on the level of nitric oxide products in $\mathrm{CD}$ patients keeping to a strict GFD correspond to those reported by Ertekin et al (15). However, the study of Hollen et al (25) reports that a part of CD patients keeping to a traditional GFD have not normalized their nitrites/nitrates after a one-year diet.

Our study has found that the breach of diet compliance in CD is accompanied by an increase of the level of nitric oxide metabolites in blood serum. It seems that an increased concentration of nitric oxide products in serum in CD can indicate the intensity of an inflammatory process in the small intestine. Documentary evidence of the supposition is the revealed relationship between NOx and total cellular density of lamina propria villi and the space between the crypts in the group of total CD patients. Moreover, it is supported by the fact we have revealed: significantly higher cellular density throughout the depth of duodenal lamina propria mucosa in children with the breach of GFD compared to those on a strict GFD. The continuing intake of gluten products in patients with diagnosed CD is supposed to result in steady inflammatory process in intestinal mucosa (26). In addition, we have found significant negative correlation between NOx concentration and villi height, and positive correlation between NOx and crypt depth in children with $\mathrm{CD}$. The revealed reduced height of villi and the increase of crypt depth in breach of GFD compared to a strict GFD is an evidence of a damage effect of gluten on intestinal mucosa in $\mathrm{CD}$ patients. According to literature reports, the damage of villi is caused by the presence of a significant accumulation of inflammatory cells in the upper part of lamina propria (27). Our findings on the correlations between nitric oxide metabolites and histological condition of intestinal mucosa in CD patients in follow-up differ from those obtained in the previous study. The latter reported of plasma NOx to be correlated with histological grade only initially (16). It may be explained by the way the small intestine bioptates are assessed. We share the opinion that only quantitative results of mucosal parameters obtained morphometrically, especially in a follow-up period, is the most sensitive and objective way to record the changes in the small intestine bioptates $(28,29)$ that enables to draw a significant comparison between them and other laboratory findings of a particular patient.

Our findings have revealed that serum NOx level in CD patients correlates negatively with the index of urinary D-xylose excretion within 5 hours that is widely used as an absorption test (30).

The study has showed that the increase in the concentration of nitric oxide metabolites in serum reflects abnormal morphology of the small intestine and its reduced absorption function in patients with the breach of a strict GFD. An increased concentration of end products of nitric metabolites in serum in children with $\mathrm{CD}$ on a semistrict GFD may also indicate high NO production.

By now, NO in body is known to be synthesized from the amino acid L-arginine by three known isoforms of NO-synthase enzyme: neuronal (nNOS), endothelial (eNOS) and inducible (iNOS). The latter synthase provides a long-standing synthesis of the greater number of NO than other isoforms. INOS promotes the pathophysiology of inflammatory diseases (31). In gastrointestinal tract iNOS is activated in many gastrointestinal diseases. In addition, $\mathrm{NO}$ and its products can have protective or tissue damaging effect (32-34).

The previous researches in intestinal bioptates in $\mathrm{CD}$ showed that in enterocytes and lamina propria of mucus there is an elevated expression of iNOS, the source of which are inflammatory cells $(11,35)$. Therefore, the increase in the level of nitric oxide metabolites in biological media in CD patients is certain to be the effect of enhanced iNOS action of the bowel.

In a number of researches there has been shown that interferongamma in combination with gliadin can contribute to the elevated expression of iNOS genes in intestinal macrophages in celiac disease $(36,37)$ that increases nitric oxide production. Bernardo et al (38) in their work found that in CD patients after the production startup of nitrites and interferon-gamma interleukin-15 induces more intense immune response that results in the production of other immune mediators and increases intestinal damage. It should be admitted that many aspects of the participation of iNOS, NO and its derivatives in the pathogenesis of immuno-inflammatory process in celiac disease are still not discovered completely.

Food intake of nitrates, the biological half-life of which is 5-8 $\mathrm{h}$ can have an impact on the level of NO metabolites in blood serum (39), and therefore, a fasting period before taking blood serum samples is recommended. In our study the blood serum samples were taken fasting in the morning after nocturnal sleep. Significant differences in the content of nitrates and nitrites between the groups of children with CD (a strict GFD and a semistrict GFD) revealed by our research are unlikely to be explained by other dietary factors but gluten.

The limitation of the method for determination of the end products of nitric oxide in serum is the impossibility to study opaque blood serum. However, in clinical practice such cases are rare. 


\section{Conlusion}

The level of stable nitric oxide end products in serum in children with CD breaking a strict GFD in a long-term follow-up period is significantly increased. The changes of serum NOx content in CD patients are significantly associated with particular morphometrical parameters of intestinal mucosa and the value of a functional absorption test. The increase of the level of nitric oxide metabolites accompanies the exacerbation of chronic inflammatory process with villi damage in the intestinal mucosa in children breaking a strict gluten-free diet. The concentration of nitric oxide metabolites in blood serum is a useful, minimally invasive and quick measured biomarker to monitor dietary compliance and the intestinal mucosa condition in children with $\mathrm{CD}$ in annual examination in clinic. Further studies will enable to improve the system of a long-term follow-up in $\mathrm{CD}$ patients and provide up-to-date information about NO participation in the pathogenesis of the disease.

\section{References}

1. Bai JC, Fried M, Corazza GR et al. World gastroenterology organisation global guidelines on celiac disease. J Clin Gastroenterol 2013; 47 (2): 121-126.

2. Catassi C, Cobellis G. Coeliac disease epidemiology is alive and kicking, especially in the developing world. Dig Liver Dis 2007; 39 (10): 908-910.

3. Mustalahti K, Catassi C, Reunanen A et al. The prevalence of celiac disease in Europe: results of a centralized, international mass screening project. Ann Med 2010; 42 (8): 587-595.

4. Lionetti E, Catassi C. New clues in celiac disease epidemiology, pathogenesis, clinical manifestations, and treatment. Int Rev Immunol 2011; 30 (4): 219-231.

5. Makovicky P. What can we do to promote the recognition of celiac disease: a report on diagnostic strategies. Bratisl Lekárske Listy 2010; 111 (3): 163-165.

6. Husby S, Koletzko S, Korponay-Szabó IR et al. European Society for Pediatric Gastroenterology, Hepatology, and Nutrition guidelines for the diagnosis of coeliac disease. J Pediatr Gastroenterol Nutr 2012; 54 (1): $136-160$.

7. Gujral N. Celiac disease: Prevalence, diagnosis, pathogenesis and treatment. World J Gastroenterol 2012; 18 (42): 6036.

8. Cirino G, Distrutti E, Wallace JL. Nitric oxide and inflammation. Inflamm Allergy Drug Targets 2006; 5 (2): 115-119.

9. Alusik S, Jedlickova V, Paluch Z, Zecova S. Plasma levels of nitrite/ nitrate and inflammation markers in elderly individuals. Bratisl Lekárske Listy 2008; 109 (7): 289-292.

10. Beckett CG, Dell'Olio D, Ellis HJ, Rosen-Bronson S, Ciclitira PJ. The detection and localization of inducible nitric oxide synthase production in the small intestine of patients with coeliac disease. Eur J Gastroenterol Hepatol 1998; 10 (8): 641-647.

11. Daniels I, Cavill D, Murray IA, Long RG. Elevated expression of iNOS mRNA and protein in coeliac disease. Clin Chim Acta 2005; 356 (1-2): 134-142.

12. Sundqvist T, Laurin P, Fälth-Magnusson K, Magnusson KE, Stenhammar L. Significantly increased levels of nitric oxide products in urine of children with celiac disease. J Pediatr Gastroenterol Nutr 1998; 27 (2): 196-198.

13. Högberg L, Webb C, Fälth-Magnusson K et al. Children with screening-detected coeliac disease show increased levels of nitric oxide products in urine. Acta Paediatr 2011; 100 (7): 1023-1027.

14. Murray IA, Bullimore DW, Long RG. Fasting plasma nitric oxide products in coeliac disease. Eur J Gastroenterol Hepatol 2003; 15 (10): 1091-1095.

15. Ertekin V, Selimoğlu MA, Türkan Y, Akçay F. Serum nitric oxide levels in children with celiac disease. J Clin Gastroenterol 2005; 39 (9): 782-785.

16. Spencer HL, Daniels I, Shortland J, Long RG, Murray IA. Effect of a gluten-free diet on plasma nitric oxide products in coeliac disease. Scand J Gastroenterol 2004; 39 (10): 941-945.

17. Rodrigues AF, Jenkins HR. Investigation and management of coeliac disease. Arch Dis Child 2008; 93 (3): 251-254.

18. Jadresin O, Misak Z, Sanja K, Sonicki Z, Zizić V. Compliance with gluten-free diet in children with coeliac disease. J Pediatr Gastroenterol Nutr 2008; 47 (3): 344-348.

19. Errichiello S, Esposito O, Di Mase R et al. Celiac disease: predictors of compliance with a gluten-free diet in adolescents and young adults. $\mathrm{J}$ Pediatr Gastroenterol Nutr 2010; 50 (1): 54-60.

20. Walker-Smith JA, Guandalini S, Schmitz J, Shmerling DH, Visakorpi JK. Revised criteria for diagnosis of coeliac disease. Report of Working Group of European Society of Paediatric Gastroenterology and Nutrition. Arch Dis Child 1990; 65 (8): 909-911.

21. Miranda KM, Espey MG, Wink DA. A rapid, simple spectrophotometric method for simultaneous detection of nitrate and nitrite. Nitric Oxide Biol Chem Off J Nitric Oxide Soc 2001; 5 (1): 62-71.

22. Sun J, Zhang X, Broderick M, Fein H. Measurement of Nitric Oxide Production in Biological Systems by Using Griess Reaction Assay. Sensors 2003; 3 (8): 276-284.

23. R: A Language and Environment for Statistical Computing. R: A Language and Environment for Statistical Computing. Vienna, Austria: R: A Language and Environment for Statistical Computing; 2013. http:// www.R-project.org/

24. Ghosh S. Advances in our understanding of the pathogenesis of celiac disease. Can J Gastroenterol 2011; 25 (4): 186.

25. Hollén E, Forslund T, Högberg $L$ et al. Urinary nitric oxide during one year of gluten-free diet with or without oats in children with coeliac disease. Scand J Gastroenterol 2006; 41 (11): 1272-1278.

26. Murray JA. Celiac sprue: to diet or digest. Clin Gastroenterol Hepatol 2005; 3 (7): 629-630.

27. Ensari A. Gluten-sensitive enteropathy (celiac disease): controversies in diagnosis and classification. Arch Pathol Lab Med 2010; 134 (6): 826-836.

28. Arikan C, Zihni C, Cakir M, Alkanat M, Aydogdu S. Morphometric analysis of small-bowel mucosa in Turkish children with celiac disease and relationship with the clinical presentation and laboratory findings. Dig Dis Sci 2007; 52 (9): 2133-2139.

29. Cummins AG, Alexander BG, Chung A et al. Morphometric evaluation of duodenal biopsies in celiac disease. Am J Gastroenterol 2011; 106 (1): 145-150. 
30. Tveito K, Brunborg $\mathbf{C}$, Bratlie $\mathbf{J}$ et al. Intestinal malabsorption of D-xylose: comparison of test modalities in patients with celiac disease. Scand J Gastroenterol 2010; 45 (11): 1289-1294.

31. Förstermann U, Sessa WC. Nitric oxide synthases: regulation and function. Eur Heart J 2012; 33 (7): 829-837, 837a-837d.

32. Lanas A. Role of nitric oxide in the gastrointestinal tract. Arthritis Res Ther 2008; 10 Suppl 2: S4.

33. Lundberg JO, Weitzberg E. Biology of nitrogen oxides in the gastrointestinal tract. Gut 2013; 62 (4): 616-629.

34. Sohn JJ, Schetter AJ, Yfantis HG et al. Macrophages, nitric oxide and microRNAs are associated with DNA damage response pathway and senescence in inflammatory bowel disease. Plos One 2012; 7 (9): e44156.

35. Niveloni $S$, Weksler-Zangen $S$, Pedreira $S$ et al. Time course of nitric oxide synthase generation after gluten exposure in the rectal mucosa of gluten-sensitive patients. Scand J Gastroenterol 2000; 35 (11): 1150-1156.
36. Maiuri MC, De Stefano D, Mele G et al. Gliadin increases iNOS gene expression in interferon-gamma-stimulated RAW 264.7 cells through a mechanism involving NF-kappa B. Naunyn Schmiedebergs Arch Pharmacol 2003; 368 (1): 63-71.

37. De Stefano D, Maiuri MC, Simeon V et al. Lycopene, quercetin and tyrosol prevent macrophage activation induced by gliadin and IFN-gamma. Eur J Pharmacol 2007; 566 (1-3): 192-199.

38. Bernardo D, Garrote JA, Allegretti Y et al. Higher constitutive IL15R alpha expression and lower IL-15 response threshold in coeliac disease patients. Clin Exp Immunol 2008; 154 (1): 64-73.

39. Hord NG, Tang Y, Bryan NS. Food sources of nitrates and nitrites: the physiologic context for potential health benefits. Am J Clin Nutr 2009; 90 (1): $1-10$. 